RACE, IMMIGRATION, GENDER, AND THE POLITICS OF EXCLUSION

\title{
"A Tent City is Not a Place for a Family": Mariel Cuban Women and Gendered Disorder at Regional Resettlement Facilities
}

\author{
Melissa Hampton \\ University of Wyoming, US \\ melissa.hampton@uwyo.edu
}

\begin{abstract}
According to sociologist B.E. Aguirre, at the height of the Mariel refugee crisis, most Americans believed that the newly arrived Cubans were "young, black, unmarried and that they were shiftless and dangerous people: prostitutes, homosexuals, mental defectives, and thugs." While this stereotype would stigmatize the larger group of Mariel Cubans and serve as the legal foundation for serve as the legal foundation for EXCLUDING OR EVEN IMPRISONING SIGNIFICANT NUMBERS OF THE MIGRANTS, it was not inevitable that the new arrivals would be understood in this way. This article explores how regional resettlement facilities in Florida, Arkansas, Pennsylvania, and Wisconsin became crucial sites in the social and cultural negotiation of the status of Mariel Cubans, as well as how refugee women, in particular, became inextricably linked to arguments levied in the principle debates and controversies concerning Mariel resettlement.

Ongoing issues in the camps like prostitution heightened the perceived criminality and undesirability of refugees and contributed to the spectacle of sex-centered disorder, specifically non-normative expressions of sexuality. Moreover, after Cubans were consolidated in Arkansas, the focus pivoted to Fort Chaffee's large group of pregnant women, repeatedly distinguished as a hard-to-sponsor, "leftover" demographic. Perceptions of criminality, sexual nonconformity, and suspicions of becoming an economic burden contributed to Cuban women's undesirability, racialization, and the increasingly militarized climate in which they resided. This article contends that "disorder" centrally involving refugee women helped to construct a new racialized understanding of Cuban refugees that challenged previous assumptions about Cuban exiles' whiteness, "Americanness," and exceptional status among Cold War immigrants.
\end{abstract}

Keywords: Cubans; refugees; detention; gender; race; women

Nearly half of Cuban refugees newly arrived in the United States in 1980 faced a dismal welcome. The roughly 62,000 Cubans not reunited with sponsors in South Florida were transferred to four military bases around the country: Eglin Air Force base in Florida, Fort Chaffee in Arkansas, Fort Indiantown Gap in Pennsylvania, and Fort McCoy in Wisconsin. The federal government set up these temporary resettlement facilities, called "camps," to house Cubans while they underwent processing by various federal agencies and waited to be matched with sponsors by the voluntary agencies (VOLAGS) working alongside the government. By midJune, the boatlift slowed down significantly, and all facilities had reached peak capacity, housing a total of 53,000 Cubans ("A Report of the Cuban-Haitian Task Force").

At the height of the refugee crisis, most Americans believed that Mariel Cubans were "young, black, unmarried and that they were shiftless and dangerous people: prostitutes, homosexuals, mental defectives, and thugs" (Aguirre 155). This stereotype would stigmatize the larger group and serve as the legal foundation for serve as the legal foundation for EXCLUDING OR EVEN IMPRISONING SIGNIFICANT NUMBERS OF THE MIGRANTS, but it was not an inevitable one. This article explores how regional resettlement facilities became crucial sites in the social and cultural negotiation of the status and desirability of Mariel Cubans. The political, economic, and social climate of the United States predisposed many Americans to a negative view of the group, and perceptions of Cuban disorder in the camps significantly reinforced these tensions. 
Female refugees made up about $45 \%$ of the Mariel population processed and released to relatives and other sponsors in South Florida from May through August 1980. Yet they made up at most 22\% of the camp population (Fort Indiantown Gap) and at the least 11\% (at Fort McCoy) ("Cuban Entrant Data"). Still, ongoing issues in the camps like prostitution heightened the perceived criminality and undesirability of refugees and contributed to the increasing militarization of these facilities. Even as federal officials sought to downplay sexual issues, the reality and spectacle of sex-centered "disorder"-specifically non-normative expressions of sexuality-facilitated the persistent segregation and reorganization of these spaces. After the government consolidated all remaining Cuban detainees at Fort Chaffee in October, one persistent focus was the site's large group of pregnant women, repeatedly discussed as a hard-to-sponsor, "leftover" demographic, destined to integrate into American life only as far as the welfare rolls. While other studies of Mariel detention focus mainly on the perceived threat of unaccompanied Cuban men, this scholarship obscures other types of "disorder" and the less visible but equally significant militarized responses to them: internal segregation and normalized gendered violence. ${ }^{1}$ This article also shifts the primary focus of camp militarization back to the summer of 1980, when a larger percentage of Cuban women and families lived in these facilities. A chronological recentering allows us to reassess the impact that Mariel women had on perceptions of camp disorder at a moment when Americans were still forming their opinions of Mariel Cubans.

The "disorderly" characterization of Mariel women in these camps is rooted in a longer history of American perceptions of (especially unaccompanied) immigrant women. Historically, the US government has categorically excluded and deported immigrant women suspected of being prostitutes, those with "illegitimate" children, whose sexuality was deemed non-marital or non-normative, and women considered "likely to become a public charge." These gendered arguments likewise affected Cuban women living in the camps. These were the sites where women's behavior was most publicly scrutinized, where Cubans were cleared for release from federal custody, and where many of Mariel's sexually and criminally suspect stayed longest. Despite their minimal chances of exclusion or deportation, Cuban women were nonetheless perceived as criminals, sexual nonconformists, and an alleged economic burden, which in turn contributed to women's undesirability, racialization, and the camps' increasingly militarized climate. For the group of unaccompanied women who remained at Fort Chaffee for over a year, these perceptions harmed chances of their resettlement. Through the deployment of older, gendered, xenophobic arguments, Mariel women became centered in larger contemporary social, economic, and political debates, particularly the deliberation over what made migrants, and explicitly Cubans, worthy of national belonging and political asylum.

These gendered understandings of migrants became entangled with newer racializing discourses about Mariel Cubans. Rooted in the real and perceived differences between the new arrivals and previous migrations of Cuban exiles, new Cubans became differentiated by their gender, age, political background, and marital status. ${ }^{3}$ The processing centers in Florida, Arkansas, Pennsylvania, and Wisconsin where the government sent these largely young, Black, and unaccompanied Mariel refugees became primary sites where discourses about Mariel Cuban difference formed for a Cuban-American and more broadly national audience. This article argues that "disorder" centrally involving refugee women helped to construct a new racialized understanding of Cuban refugees that challenged previous assumptions about Cuban exiles' whiteness, "Americanness," and exceptional status among Cold War immigrants.

\section{Mariel "Disorder" Through the Lens of the Press}

By the time Cubans arrived in the camps, rumors that the boatlift contained many criminals had caused the media to become deeply invested in the resettlement effort. Scholars have noted the implications of widespread media coverage of Mariel resettlement, particularly its role in crafting and circulating damaging portrayals of the refugees. ${ }^{4}$ This article builds on these observations, but focuses instead on largely unexamined issues in the camps and the contexts in which they garnered public attention. The consistent scrutiny of confined Cubans delayed the sponsorship process and reoriented federal procedures. Federal

\footnotetext{
${ }^{1}$ Other scholars have explored the militarized nature of domestic refugee camps and situated Mariel confinement in the roots of migrant detention, but they have generally focused on the most high profile "disturbances" to occur at these facilities and the most visible militarized responses to them. See Lipman. See also Shull. Scholars moreover have examined camp confinement to anticipate Mariel incarceration in federal prisons. These analyses focus on "undesirable," "un-sponsorable," and unaccompanied Mariel men and the period of refugee consolidation at Fort Chaffee beginning in the fall of 1980. On long-term Mariel incarceration see, for example, Dow, Hamm. It should be noted, however, that most Mariel Cubans did not end up in such long-term detention.

2 See, for example, Luibheid, Gardner, Moloney.

${ }^{3}$ For more on the demographic characteristics of Mariel Cubans see, for example, Pedraza-Bailey; Bach et al.; Briquets.

${ }^{4}$ See, for example, Hufker and Cavender; Portes; and Stepick; Jacklin; Aguirre; Fernandez.
} 
officials acknowledged the impact the press had on the resettlement effort and closely monitored accounts of camp life through the public relations arms of FEMA, the branches of the military, and later, the new Cuban-Haitian Task Force.

In 1984, Army historian Frank Pew reflected back on the U.S. military's role in the resettlement process. In the Army's report, he recounted relationships that had developed among state officials, national and local media, and camp personnel. Pew emphasized the law enforcement angle of Wisconsin media's interest in Fort McCoy and perceptions of Mariel criminality that fueled local interest. He admitted that, due to these adverse perceptions, it was camp security, the maintenance of order, and any threats to this order that became the primary issues through which public views of the refugees came to be framed. The role of the military police and law enforcement officials were therefore prioritized over other programs and functions of the resettlement effort. He claimed that it was through this lens and these actors that the story of Mariel confinement would subsequently be told (241-242).

The dynamics that Pew describes between the federal government, state officials, and the media are another focus of this article. I build on the defining role of law enforcement in public interest in these refugees and narrate how women became entangled in larger conversations about refugee criminality, their impact on local communities, and on federal efforts to segregate and militarize these spaces. Significantly, Pew references prostitutes among the categories of Cuban criminals that fascinated local news outlets. Indeed, sex work, both as a perceived characteristic of Cuban deviance and as a problem in the camps, was a topic upon which larger national anxieties were projected. As the U.S. continued to contend with the prospect of integrating new Cuban exiles, the issue of these women's sexual criminality would expose both the processes of increasing Mariel racialization and the stakes of reconciling this stigmatization with an older, privileged understanding of Cuban refugees. To begin the story of refugee processing at these four facilities, and to better understand how gendered conceptions of Mariel criminality developed in these spaces, it is to the subject of prostitution that I turn first.

\section{Illicit Activities and Disorderly Spaces}

The racialized understanding of Mariel prostitution, and of unaccompanied women more generally, became evident as a spectacle of disorder began to emerge at the camps. Camp life was generally characterized by monotony, waiting, and frustration with delays in the custody release process. Processing problems drove this escalating discontent. Frustration and hopelessness fueled multiple acts of resistance by detainees, including many highly-publicized escape attempts. For example, on June 1, met with police fire and other violence, the Cubans hurled sticks, bottles, and concrete at law enforcement officials and set fire to some of Fort Chaffee's buildings. Emergency measures to pacify increasing hostile local public opinion towards the refugees at Fort Chaffee included the establishment of a disciplinary stockade, the construction of a barbed wire border fence, and the stationing of state troopers outside the camp. Stigmatization preceded the Cubans arrival at the facility, but Gaston Fernandez maintains it was "amplified by the propensity of local political leaders, the media and public opinion to portray all forms of Marielito protest as evidence of pathological behavior" (43). According to Jana Lipman, this type of militarized response to refugee unrest "served to exaggerate the danger and oppositional politics of the marielitos" (79).

Unrest in late May and early June brought additional interest to the perceived deviance of these spaces. Following an escape attempt at Eglin, the Orlando Sentinel published a feature devoted to the practice of the 'oldest profession' at the Base. Despite women's reported marginality to camp violence, the account revealed a thriving subculture among Eglin's unaccompanied women that bolstered perceptions of Mariel Cuban criminality and difference. Describing the women and girls who "ply their trade in the male dominated Cuban population," the Sentinel revealed that to the dismay of refugee families, they "walked around the camp at dusk ... wearing provocative clothing and winking and cooing at the multitudes of single men." In noting how at least one male refugee steered clear of the prostitutes for fear of getting "sick," the reporter linked Cuban prostitutes with another circulating anxiety about Mariel migrants: concern that they brought venereal disease to the camps (J. Williams). In their histories of Mexican American women living in Los Angeles during World War II, Catherine Ramirez, Elizabeth Escobedo, and Vicki Ruiz have argued that sexually deviant constructions of "pachucas" in the press (especially as prostitutes) played a key role in the group's racialization, marking them as un-American and outside of the boundaries of acceptable wartime citizenship. Public attention reinforced the now-familiar claim that prostitutes were the female version of male criminals or Cuban "scum" that Castro intentionally dumped into the boatlift and strengthened the perception that unaccompanied women were symbolic of Cuban deviance. 
Despite acknowledging the marginal conditions under which many refugees had previously lived, the Sentinel nonetheless sexualized Eglin's refugee women and reinforced their continued desire to practice their "trade" in the newly-designated Liberty City. Deirdre Moloney argues in her examination of the exclusion and deportation of immigrant women suspected of prostitution at the turn of the twentieth century that "the threat of immorality was defined as an external one, which immigrants brought with them from their own societies, rather than as a response to changes within American society, culture, and its economy" (53). Similar imagery denoted the foreignness of Mariel women and contrasted their sexuality with a set of imagined American gender and sexual norms. Alongside the attitudes expressed at other camps by disaffected members of camp law enforcement, the Sentinel's report also naturalized distinctions between Mariel women and Cuban refugees who had left before the island's political, economic, and social transformation. These perspectives suggested that Mariel women growing up under communism either had little interest in rehabilitation in their new nation or had little opportunity to gain occupational skills to transcend their immoral lifestyles. Unaccompanied, socially marginalized women evoked far less sympathy than refugee families in discussions of migrant poverty. These prostitutes represented economic precarity in addition to social and generational undesirability. In an earlier era in which many Americans feared another "great wave" of migrants that threatened the political, economic, and moral underpinnings of the United States, "migration within family groups was increasingly seen as desirable and as a stabilizing factor among immigrant workers, which would insulate them from poverty and, in some cases, criminal activity" (Moloney 88). ${ }^{5}$ Gender and class anxieties about unaccompanied Mariel women mutually constituted racialized, economic assumptions about their national belonging at a time when the financially fraught country was divided in its acceptance of an ever-growing number of "economic migrants."

In the wake of refugee unrest at Fort Chaffee, the press also fixated on an area of the camp known as the "Boulevard." Said to be the "breeding ground" where many of the ringleaders of the June 1 incident resided, both refugees and officials believed the Boulevard to be the center of the camp's criminal activity (United Press International, "Troops Find Weapons"). Accounts of prostitution quickly appeared alongside those of violence and trouble (Waldschmidt). The Miami Herald highlighted the 'hard cases' that Fort Chaffee housed, including prostitutes who had "set up shop" in the camp's centrally-located district (Fiedler and Gugliotta). Despite increasingly restricted access, regional papers like Louisiana's Shreveport Times sent reporters and photographers to Fort Chaffee in the wake of the violence and penned similar accounts of the Boulevard's reported prostitution and place within a larger criminal subculture (Durrett). ${ }^{6}$ Prostitution on the Boulevard became linked to other illicit activities, notably the emergence of a black market, in this section of the Fort. New security measures were aimed at policing the space, including regular weapons raids and permission for troops to use nonlethal force (United Press International, "Troops Find Weapons"). When the Carter Administration began to condemn Castro publicly for sending over Cuban criminals in violation of international law, Mariel sex workers simultaneously became a specific and publicly recognized feature of Fort Chaffee's criminal subculture and burgeoning black market. ${ }^{7}$

Focus on Fort Chaffee's Boulevard further racialized Mariel Cubans. In reporter Paul Waldschmidt's widely reprinted account following the violence, he referred to the Boulevard as the area of the camp "that families move out of and tell their children to stay away from; where almost anything can be found for a price, where problems start and where police have the most problems." Comparisons to other "bad part[s] of town" invited readers to imagine how the main artery of the camp resembled the many inner-city communities throughout America where Brown, Black, and other racial minorities were clustered. At least one reporter drew comparisons between the Boulevard and the nineteenth-century American West to highlight the criminality and deviance of its residents. Describing how prostitution fit right in to "scenes reminiscent of an early frontier town," a Cuban American freelancer reporting for the St. Louis Dispatch emphasized the "open" nature and the relative lawlessness of the activities at Fort Chaffee (Rivero).

\footnotetext{
${ }^{5}$ Moloney's work also demonstrates that gendered economic arguments for immigrant women's exclusion differed according to their race and ethnicity and adversely affected non-European immigrant women from the Caribbean. By the 1920s and 1930s, the LPC (or "likely to become a public charge") provision of federal immigration laws was used to police and deport immigrants of color, including men, more broadly. For a larger discussion of the LPC clause's effects on Latino immigrants in the interwar period, see Ngai.

${ }^{6}$ Notably, reporters for wire services and regional papers often discussed prostitution on the Boulevard and other spaces of the camp only as rumors, emphasizing that women were "reportedly" engaging in commercial sex.

${ }^{7}$ For other references to prostitution in relation to Fort Chaffee's black market, see, for example, Fiedler and Gugliotta, Durrett, CoxHerion; Rivero. These accounts were printed in the same news cycles as articles that further implicated Mariel women as criminals and located them in the camps. The AP, for instance, revealed that a former female Cuban hijacker had recently been identified and arrested at Fort Chaffee. See, for example, "Troops Find Weapons" and Perez.
} 
Reporters' fixation on illicit activities, theft, and the black market pathologized the group. Scrutiny of these spaces obscured how the refugees' distrust of Cuban authorities and the Cuban state informed their misgivings towards U.S. officials. ${ }^{8}$ Observers' comments on the state of prostitution at Fort Chaffee entangled the sexualization of Mariel women with this pathological misunderstanding of refugee circumstances and opportunities. Reporters and on-site officials participated in the racialization of Mariel women by pointing, for example, to the inexpensive rates that prostitutes were rumored to charge (Rose, Lynn). Alongside comments that Cuban refugees came from "simple backgrounds" and were not accustomed to using toilets or taking care of their own babies, these attitudes conveyed that refugee women's non-normative qualities were deeply rooted and the natural result of being raised under a non-democratic, backward, Third World political and cultural regime. ${ }^{9}$

The violence at Fort Chaffee was also the catalyst for an in-depth story by the Lebanon Daily News, which was eager to investigate whether a Chaffee-like riot was possible at Fort Indiantown Gap. Based on interviews with refugees and base employees, the story suggested that the tension between unaccompanied refugees and families would be the spark that would ignite violence at the "tense" processing facility. The reporter wrote that "pent-up" men who had "been too long without women" would enhance the potential for violence. Anticipating unrest at the Gap, officials increased security measures, including the expansion of Military Police and Federal Protective Service officers on site (Lenton). In addition, the Chicago Tribune called attention to the "potential for [similar] trouble and unrest" at Fort McCoy, since a disproportionately large number of single men lived there "without the equalizing influence of women and children." The Tribune relayed the nascent unrest and potential for violence at Fort McCoy in decidedly gendered terms and suggested that the skewed ratio of individuals to families created a climate where prostitution could flourish. A "civilized" internal security unit led by Cubans was necessary to keep the "troublemakers" in line, it argued (Keegan)..$^{10}$ As camp violence (or its potential) focused attention on the Boulevard and similar types of camp spaces, disorder became increasingly defined by the rising tensions and frustrations between unaccompanied Cubans and Mariel families.

\section{"Good" Versus "Bad" Cubans}

Confined Cubans' attitudes constructed this particular understanding of camp disorder. Public scrutiny of each camp's criminal subculture compelled new Cubans to distinguish themselves politically, socially, and culturally from other new arrivals. When news of unrest at Eglin Air Force Base and Fort Chaffee reached the public, the stakes of preserving the image of Cuban refugees peaked. ${ }^{11}$ Since the 1959 Revolution, most exiles had fashioned their identities in opposition to Castro's politics (de los Angeles Torres, García, Havana U.S.A, García, "Hardliners vs. Dialogueros"). During the 1960s and 1970s, Cuban migrants benefitted from a range of federal benefits and support, including a federally-sponsored initiative to promote a positive image of the exiles. Carl Bon Tempo and Cheris Brewer Current have explored the ways in which state-facilitated representations of early Cuban refugees strategically linked anticommunism and whiteness to their middleclass identity. Cubans both inside and outside resettlement camps became increasingly aware of the implications of negative press coverage of the Mariel crisis for their desirable status. It could tarnish the group's overall image, lower rates of sponsorship, and taint the debate over Cuban legal status and federal aid. Voluntary agencies and the government's public affairs staff worked to destigmatize the new arrivals in the press and to normalize perceptions of even those who had served time in Cuban prisons. But older refugees, and Mariel families in particular, lessened the impact of this effort by drawing attention to important differences they perceived with the larger group of unaccompanied Cubans. For Cubans even temporarily detained in these facilities, adverse experiences motivated them simultaneously to defend the larger group of refugees and to distance themselves discursively and physically from the 'criminal element.' Many newly

\footnotetext{
8 For further discussion of these dynamics, see Lipman; Fernandez.

9 Ironically, while a variety of American actors including exiles themselves would single out Cuban prostitutes as important symbols of the failures of Revolutionary society, Fidel Castro used this publicity back in Cuba to reinforce the capitalist underpinnings of sex work and marginality of sex workers to the Revolutionary project. As Rachel Hynson has argued, the Cuban government "transitioned from viewing prostitutes as victims of capitalism-forced into prostitution by economic inequality-to 'criminal manifestations' who rejected the opportunities provided by the Revolution." Since the regime's initial approach to the issue involved paternalistic "reforming" and re-educating Cuban sex workers to focus on the family, by 1966 Fidel Castro proudly announced the near-elimination of prostitution on the island, adding this feat to the "grand narrative" of the Revolution. See Hynson pp. 151-152, p. 195. For more on how the perceived loose sexual morals and behavior of Latina women has been linked to their specific ethnic, national, and specifically, socio-political background, see Escobedo p. 135 and Chavez pp. 76-77.

10 See also White.

${ }^{11}$ For more on the exceptional status and reception of Cuban refugees during the Cold War, see Current; Bon Tempo; Casavantes Bradford.
} 
arrived refugees (often unintentionally) contributed to the construction of Mariel difference and the group's subsequent stigmatization in their desire to maintain the favorable reception that previous generations of exiles had enjoyed.

Emphasizing the social disorder caused by the presence of prostitution in the camps was a primary way in which refugees sought to discredit the population of unaccompanied men and women that they shared living spaces with. In the press and to visiting Cuban American advocates, refugees consistently objected to living among those who they believed were politically and socially less desirable (J. Williams, Press). Federal officials publicly downplayed criminal activity but also echoed the concerns of camp families. In the St. Petersburg Times, FEMA emphasized that Eglin was ultimately "not a pleasant place to live." By maintaining that "a tent city is not a place for a family," they helped fuel public anxieties that the makeup of Cuban refugees had changed with this new influx and that disorderly resettlement procedures were a direct result of changing demographics (McMahon).

FEMA's public support of refugee families reflected their internal concerns about the camp's social climate and prostitution's presence there. Federal daily operational summaries from mid-to-late-May reflect that the agency understood camp tension to be mounting at both Eglin and Chaffee because of "bad guys and bad girls," or specifically, gay men and prostitutes. Federal officials emphasized that these camps held "more than their share" of these groups and pointed to ways in which these "rabble rousers" caused "unrest" and motivated efforts to move large numbers of refugees between camps ("Operational Summary"). FEMA's Cuban American advisor and Miami Assistant City Manager, Cesar Odio, reinforced these concerns when, after a brief walkthrough at Eglin, he reported the unfavorable mixing of families and prostitutes ("Significant Activities 17 May"). Officials proposed moving an estimated 2,000 prostitutes and gay men to Fort Chaffee but acknowledged that Fort Chaffee ultimately had similar problems ("FEMA/Miami Coordination"). They determined that the "very hostile situation" at Eglin also resulted from slow processing and sponsorship of refugees Officials were therefore concerned that prostitutes, as un-sponsorable, "undesirable" individuals, would not be leaving anytime soon, failing to alleviate mounting social tensions.

Fort Chaffee was not immune from a similar indictment by its own refugee population (Rivero). In the UPI piece that introduced readers around the country to Fort Chaffee's "tough district," 'good families' increasingly moved out of the camp's Boulevard section when they found 'bad people' (including prostitutes) had taken up residence. At the same time that refugee families moved away from the Boulevard, single young men and women were reported to have simultaneously "gravitated" to this area (Waldschmidt). After the events of June 1, the camp's refugee leaders were likewise reportedly responsible for requesting a weapons raid on the Boulevard, which garnered additional damaging coverage (United Press International, "Troops Find Weapons"). Catherine Ramirez notes that, in addition to being labeled as sexually-deviant, Mexican American pachucas during World War II were stigmatized because of involvement with illegal gang activity, riots, and other deviance. This perception of bad behavior, "condemned as masculine," contributed in large part to the group's racialization in Los Angeles (72). Mariel's women's presence on the Boulevard and their involvement in the space's illicit activities likewise heightened the public's understanding of Mariel women as criminally inclined, socially undesirable, and ultimately, un-American.

Refugees at Fort Indiantown Gap also testified to the tension and disorder caused by the large contingent of young, unaccompanied Cubans. Because of an alleged lack of support from the camp's military law enforcement, former political prisoners who ran self-governing councils at the Gap told the Pittsburgh Press that they were advocating to separate refugee families from "undesirable elements" (Viglucci). In this context, Fort Indiantown Gap used its aptly titled camp newsletter, La Libertad, to amplify the voices of refugees most interested in distinguishing themselves from the "troublemakers" (Lipman 76). ${ }^{12}$ In a column geared towards the camp's women, a refugee journalist offered her advice to other refugees as part of an effort to "Americanize [them] and try to prepare them for life outside the Gap" (Wilks). In one column in June, she called on refugee women to use their leisure time in the camps wisely and avoid actions that would "give Cubans a bad reputation" (La Libertad).

Differences in age, generation, and familial attachments collectively influenced Cubans' (and in turn, the public's) understandings of "good" and "bad" refugees. Dichotomous language obscured similarities among refugees, the underlying political, economic, and social conditions that shaped their inequalities, as well as migrants' circumstances in leaving Cuba. Discussions of camp prostitution and the unaccompanied women

\footnotetext{
${ }^{12}$ For more on the role that refugee camps have played in disciplining migrants and serving as sites of acculturation, see, for example,
} Espiritu; Malkki. 
who liaised with unaccompanied men stigmatized Mariel women. Like federal officials, refugee families' criticism reinforced the gendering of Mariel migrant criminality and conveyed to the public that "bad" refugee women were a homogenous, hypersexual group. By condemning young, unaccompanied refugees alongside prostitutes (and their shared living spaces), older refugees helped to police both criminalized and non-criminalized forms of sexual behavior. The separation of many families (either in Cuba or prior to their movement to these long-term centers) played an important role in the experiences and attitudes of those confined in camps, especially intact families' awareness of their own minority status. While many unaccompanied refugees did in fact have spouses, partners, children, and parents outside of the camps, other refugees still judged them based on their unaccompanied status and their new sexual relationships and other social bonds. More broadly, as knowledge about the new Cubans continued to disseminate outside of the camps, public discussions of the group elided the economic, social, and legal impacts of family separation on these increasingly infamous "single" men and women.

Similarly, Mariel women who chose sex work were understood to have transgressed and violated sexual norms. Susana Peña maintains that sexual nonconformity, along with racialization and class stigma, were "embedded in coverage of the Mariel migration, reinforcing the notion that these migrants were no loss to Cuba and posed a potential problem for the United States" (28-29). In addition to attracting substantial media attention, gay refugees, she argues, were also a "problem population" in the eyes of federal officials. Officials, reporters, and other refugees often lumped prostitutes and gay refugees together. Their marginal sexuality and perceived threat made them collectively visible. ${ }^{13}$ Refugee families in particular expressed discomfort and fear living close to both groups (J. Williams, Waldschmidt, Viglucci). ${ }^{14}$ When forced together, some refugees maligned others for blatantly displaying their sexuality in ways prohibited back in Cuba (Viglucci). ${ }^{15}$ According to their various critics, both of these groups' flagrant violations of normative sexuality were especially objectionable in the camp environment, whose primary function was to Americanize new refugees and culturally prepare them to become integrated into U.S. society.

Finally, the press situated the problems families encountered on the Boulevard in the context of a broader division among Mariel Cubans released from federal custody in South Florida and those living in camps. Journalist Alina Rivero's contrasting of the crowd of children she encountered at the ostensibly criminalfree Opa Locka processing facility near Miami with the 'ungrateful' individuals that instigated 'trouble' at Eglin Air Force Base and Fort Chaffee emphasized how distinct groups of Cubans occupied various kinds of resettlement spaces and, in turn, experienced vastly different resettlement rates. Anita Casavantes Bradford has argued that media attention to refugee children during previous migrations "helped secure sympathy and support for Cuban exiles ... by downplaying their racial and cultural similarities to other Latina/os, working-class immigrants, and minorities and emphasizing their anticommunist policies and the middleclass Christian family values they shared with mainstream Americans" (4). Intact Cuban families indeed made up a far smaller population at regional camps than unaccompanied individuals, but Rivero's account nevertheless reinforced the understanding that camps were the most disorderly types of resettlement sites, characterized by their criminal atmosphere and lack of familial influence.

Combined with the attitudes of local communities and federal officials, Cuban perceptions helped to consolidate the notion that resettlement camps were disorderly, hostile spaces home to marginal individuals. This in turn helped to justify camp segregation and militarization, aimed at policing criminals and troublemakers not considered worthy of a refugee's welcome. In the overlapping contexts of this increasingly militarized welcome and the media's sustained interest in camp law enforcement, refugees' own biases and resentment helped to further distance Mariel Cubans from a position of national belonging. Although officials were aware of the positive influence that mingling refugees had on morale, they continued to brainstorm and implement efforts to segregate 'good' from 'bad' Cubans. While often motivated by good intentions and the desire to secure safer waiting spaces for families, these efforts ultimately came at the expense of many Cubans, including the "camp families" who had formed among unaccompanied refugees. Moreover, these militarized segregation tactics had punitive consequences. At several of the camps, these

\footnotetext{
${ }^{13}$ Along with Pena, Historian Julio Capo, Jr. examines how U.S. immigration policy dealt with the tension of welcoming anti-communist exiles in an era when exclusions based on sexual orientation were explicitly written into immigration policy. Capo also suggests that gay Mariel Cuban migrants played an important role in the transformation of late Cold War immigration policy.

14 See also Pereira, "Letter to Victor H. Palmieri."

${ }^{15}$ As pointed out by Cuban American Sergio Pereira (see discussion in next section), refugees' concerns about homosexuality stemmed in part from their relationship to Cuban policies. Legal reforms in post-revolutionary Cuba had codified the criminal status of both prostitution and homosexuality.
} 
changes also empowered newly-formed Cuban internal security forces, which, when left unchecked by the federal government, would only magnify refugee disorder.

\section{Increasing Militarization}

By mid-June, comparisons to other camps continued to direct public attention to Pennsylvania's Fort Indiantown Gap and Wisconsin's Fort McCoy, where increasing processes of militarization influenced understandings of refugee disorder. On June 12, the Associated Press and United Press International reported that two Cuban women had been moved from Fort Indiantown Gap to Cambria County Jail in Ebensburg, Pennsylvania to await deportation proceedings (Associated Press, "2 Cuban Women Jailed"; United Press International, "2 Cuban Women Jailed"). Suspected prostitutes, the women were removed from the camp because, in addition to possessing criminal records that made them potentially excludable under immigration law, Gap authorities had deemed them 'potentially harmful to the general public.' Moreover, federal officials informed the county jail that they could expect up to twenty-five more transfers of prostitutes in the coming weeks. While prostitution was already established as a disorderly feature of camp life, federal efforts in this case suggested that sex work was more than merely a natural development and a nuisance to onsite officials. reported alongside news of thirty-one Mariel man transferred to federal prison from Fort Chaffee, these cases more substantially connected Mariel women to the larger contingent of Cubans deemed 'criminal' enough to be moved to higher levels of federal detention. Deportation scholars like Moloney have argued that merely the "threat of deportation contributed to the marginalization of immigrants and their stigmatization during periods of national crisis" (10). Some regional papers juxtaposed their version of this story with an image of one of the Black refugee women being escorted away from the Gap by Cambria County Sheriff's deputies, so Mariel women too became implicated as (racialized) threats to American sponsors and to others who might encounter them in the resettlement process (Associated Press, "Two Cuban Women Sent to Cambria").

As at other facilities, employees at Fort McCoy attributed the majority of camp problems to unaccompanied Cubans, reinforcing the ever-hardening distinction between troubled unaccompanied Cubans and Mariel families (Langenkamp, Buelow). Emphasizing the distinct experience of working with Cuban refugees, the Green Bay Press-Gazette noted how one officer "never thought he'd be part of a raid on a house of prostitution" (Langenkamp). Camp employees and military officials interviewed by the La Crosse Tribune, the Des Moines Tribune, and the Wisconsin State Journal echoed these attitudes. Prostitution was now a concern to officials at all four refugee processing facilities (Buelow, Gordon, Jaeger).

From the outset, Mariel women were also at the center of the "fence jumping" problem at Fort McCoy. The Green Bay Press-Gazette and the Wisconsin State Journal were among the regional papers that revealed prostitution, and even mere rumors of its presence, as a primary cause of Mariel men's desire to leave their designated areas of the camp (Langenkamp, Jaeger). As fence jumping and other unauthorized entries of unaccompanied men into women's living spaces enabled illicit fraternization between segregated populations, military officials believed it further encouraged prostitution (Pew 230). When raiding 'cat houses' became a notable function of the military police and other Fort McCoy law enforcement, prostitution appeared as yet another obstacle to camp order. But federal officials revealed that they sometimes hesitated to shut down the illicit activities of refugee women at Fort McCoy because it was one of the only ways they could consistently identify and apprehend "escaped" men. As the bait, Cuban women served as 'mousetraps' and a policing mechanism for the maintenance of order (Langenkamp). In this way, some officials' conditional acceptance of prostitution helped to draw public attention to the issue.

As officials negotiated the place of prostitution in their larger apparatus of order enforcement, newspaper reporters were not the only interested visitors to the camps. After unrest at Eglin and Chaffee, the Carter Administration appointed Sergio Pereira, a high-ranking Cuban American Dade County official, to serve as a temporary advisor to the State Department and to Victor Palmieri, the Department's U.S. Coordinator for Refugee Affairs. During his June tour of all four facilities to help the Administration assess the resettlement effort, Pereira ranked the presence of prostitutes (alongside gay refugees) as one of eleven common problems. Although working for the government, Pereira was hired to represent the interests of the Cuban American community, which that community perceived to be lacking as the resettlement effort moved from South Florida to more isolated regions. Like those of reporters, the impetus for his tours of the camps was based in part on interviews with disgruntled refugees. Pereira maintained that these women's "influence is not desirable" for families or minors, but he argued that their presence had broader implications for maintaining order. Though acknowledging that refugee women had turned to prostitution "in an effort to obtain money or favors," he argued that "allowing the prostitution trade to continue to flourish in the camps is inviting 'territorial' and 'domestic' disturbances with the potential for violence." "The women also pose a 
potential for corruption (in terms of bribery) among military and civilian staff," he elaborated. Critiquing the uneven policies of officials towards prostitution, Pereira recommended to the State Department that 'career' or 'practicing' prostitutes should be segregated from the rest of the camp, including unaccompanied males, and especially families and unaccompanied minors. Alternatively, 'women who are not prostitutes,' i.e., those who only admitted to using the label, and those who sought rehabilitation should be separated, along with other 'unattached' women (Pereira, 'Letter to Victor H. Palmieri'). In line with press critiques of camp life, Pereira's delegation came away with notable concerns about camp living arrangements, especially the cohabitation of Cuban "singles" and families, a practice they deemed "not ... healthy" (Knarr).

Pereira's recommendations were not formally acknowledged by the State Department for several months, but the federal resettlement effort clearly adapted to both internal complaints about prostitution and external press coverage. As June transitioned into July, officials in some of the camps began to segregate refugee women identified as prostitutes. In an early July reconsolidation effort at Fort Chaffee, they designated areas within the camp for prostitutes and gay men. Identified women were sent to a special section of two buildings newly outfitted with barbed wire and set aside for unaccompanied females (Department of the Army III-III-B). Aside from segregation, the issue of prostitution became entangled in other militarized efforts to institute order. On the heels of Fort Indiantown Gap's transfer of women to the Cambria County jail, officials at other camps emphasized that prostitutes and other criminals were being "weeded out" and the physical spaces where they resided "swept clean." Also by July, Cuban-led internal security forces and self-governing councils at Fort Indiantown Gap and Fort McCoy had coordinated with military and civilian authorities to police prostitution (Shelton, White). These internal security units, made up primarily of former Cuban political prisoners, were initially organized in response to prostitution and to prevent refugee "infighting" caused by the practice (White; Nickeson, Johnson; and Schaffer).

Continued public scrutiny of camp prostitution as the summer months wore on reflected internal tensions and disagreements among the various organizational elements that helped to maintain the camps. In July, the State Department created the inter-agency Cuban-Haitian Task Force (CHTF) to take over FEMA's role of coordinating resettlement at the camps. FEMA and the State Department took some steps in these spaces to police Mariel women and other refugees, but they remained most committed to the expedited release of Cubans and to managing a public relations disaster. This effort included downplaying the new characterization of these spaces as concentration camps (Lawson). ${ }^{16}$ As a result of the Task Force's efforts to try to balance refugee civil rights with sporadic refugee unrest, other camp officials and the public blamed it for not doing nearly enough. Members of the military were especially critical of existing procedures, especially those designed to limit their abilities to crack down on the "criminal element" (Adams) ${ }^{17}$ The military understood their strained relationship with civilian federal authorities to be influenced in part by FEMA and the State Department's "meaningless or nonexistent" disciplinary actions towards illegal refugee offenses, including prostitution (Pew 223-224). Alternatively, members of the military were themselves accused of encouraging prostitution and compromising camp order. Federal leadership increasingly relied on Cubans to fill the law enforcement gap, and these critiques of camp law enforcement practices would only intensify. Ultimately, as disgruntled officials continued to characterize Cubans according to their criminality, they simultaneously aimed their resentment at other federal authorities and the resettlement bureaucracy. Like the role it played in revealing emerging social tensions among refugees, the issue of prostitution betrayed divisions among camp officials. In turn, it also defined both public and private understandings of employee resentment and camp disorder.

\section{Camp Consolidation and the "Leftover" Cubans}

The Task Force began planning for the consolidation and segregation of all remaining Mariel refugees still in detention at Fort Chaffee by the end of the summer. Based on recommendations by the facility's military staff, the plan called for consolidation on two levels: physical and social. That is, officials based the separation of refugees on patterns they had observed in the preceding months, and with an eye to protecting

\footnotetext{
${ }^{16}$ In response to Pereira's recommendations, Barbara Lawson of the Cuban-Haitian Task Force admitted in September that prostitution in the camps "has been a difficult problem to control, human nature being what it is." Nevertheless, representing the Task Force's continued ambivalence towards the issue, she maintained that sponsorship had solved much of this particular problem, as well as the Task Force's partnership with Job Corps, who took some of the women "to assist them in a career change."

${ }^{17}$ Although U.S. criminal laws applied to the Cubans detained in federal custody (or in the case of Fort Indiantown Gap, state criminal laws), "as a practical matter" Task Force officials did not often formally charge or prosecute Cubans who committed crimes in these facilities. They consistently cited the "minor" nature of most offenses, lack of "substantial" evidence, and the hesitancy of victims to testify as reasons for this decision. The government also located justification for its actions in the plenary power of the INS and its ability to "detain illegal aliens in any way it sees fit."
} 
groups deemed most likely to maintain the reality or image of order. Area I would contain "legal families," "single women of good character," and Cubans over 60 years of age. Area II was reserved for "couples living in joint domicile" or "camp families." "Homosexuals and prostitutes" would reside in Area III, with "single men of good character" in Area IV. Area V was set up as a heightened security area for offenders, while Area VI would house minors (Pereira, "Letter to Chris Holmes"). Like the earlier re-segregation of refugees at the Fort, this separation likely sought to lessen tensions between so-called "legal families" and the larger population of unaccompanied males and females ("Problems Encountered by GSA Region 3"). ${ }^{18}$ Officials were not explicit about how they determined "good character," but this segregation model suggests that concerns about refugee sexuality figured prominently. ${ }^{19}$ While this consolidation planned and allowed for separate living spaces for different types of families, now, more than ever, officials were invested in delineating physical and moral boundaries between groups.

From September 25 to October 9, over 8,000 Cubans still in detention were consolidated at Fort Chaffee in this new arrangement. By this time, over 50,000 Cubans had been resettled through the four camps. Of those consolidated, 93\% were unaccompanied adult men. Unaccompanied adult women made up only $2 \%$, and families 3\% of this group. Reflecting their limited ties to the Cuban American communities in the United States and the growing effects of racism on the sponsorship process, about $75 \%$ of the remaining population was Black ("A Report of the Cuban-Haitian Task Force"). As consolidation commenced, demographics would significantly shape the perceptions and experiences of those who remained. After several months in federal custody, the media portrayed individuals and families who had yet to be sponsored as an unwanted population of "misfits" ("Castro's Big Joke"). Journalists imparted important differences among the heterogeneous mix of unsponsored Cubans, but their coverage of refugee poverty, pregnancy, and mental illness profoundly reinforced the perceived undesirability of the larger group. This attitude not only downgraded the status and deservingness of remaining Cuban exiles, but also constructed a new kind of immigrant 'underclass,' akin to the African American 'underclass' allegedly developing in America's changing cities. ${ }^{20}$

Perceptions of Mariel women's non-normative sexuality, nontraditional family structure, out of wedlock pregnancies, economic marginality, and mental illness shaped their undesirability. Indeed, sympathetic attitudes towards refugee families waned as a new kind of camp family moved into the specially-designated section of Fort Chaffee initially reserved for families who had arrived together. ${ }^{21}$ The camp's large group of pregnant women in particular was repeatedly distinguished as an un-sponsorable and undesirable 'problem' population. ${ }^{22}$ In the context of larger racialized debates over U.S. welfare reform, Mariel women and their families transformed from one of the most desirable groups to arrive in the boatlift to one singled out for their contribution to the nation's growing problems. The evolving debate over the American welfare state continued to pit a constructed group of white taxpayers against an increasingly visible group of nonwhite tax "takers," and the conversation concerning the tax burden of Mariel migrant women and their families downplayed the potential social and economic contributions of Cuba's newest arrivals. ${ }^{23}$

While this gendered xenophobia became part of the national discourse most visibly in the post-consolidation period, local manifestations of these attitudes had their roots in the earliest months of the resettlement effort. In response to a handful of local stories printed in the Lebanon Daily News in late May and early June, one Pennsylvanian drafted a "disgusted" letter highlighting the perceived economic burdens of refugee women and their families. The author, reacting specifically to the emergency health care offered to refugees at Fort Indiantown Gap (including the services given to a refugee mother in labor), predicted that

\footnotetext{
18 Reflecting on the problems that Federal Protective Service officers encountered in their internal security duties at Fort Indiantown Gap, the agency blamed high ranking civil officials at the camp for failing to create timely policies governing the segregation of these groups and other troubling populations from the rest of the refugees.

${ }_{19}$ For more on government attempts to segregate gay refugees in resettlement camps, see Pena.

${ }^{20}$ Marisa Chappell has argued that critiques of AFDC and female-headed families were key to the growing anti-welfare movement in the 1970s, as they helped to construct a "dangerous, perhaps irredeemable 'underclass' of poor minorities" in the nation's urban centers. Journalists also played an important role in popularizing this new genre of "underclass ethnography," which became a common feature of media discussions of poverty and welfare into the 1980s. (141-43). See also Solinger for a discussion of how the mainstream media disparately portrayed the choices of Black and white single motherhood during the sexual revolution (237).

21 In June 1981, the Philadelphia Inquirer emphasized that there were no longer any children older than one year living at Fort Chaffee. See Pogue.

22 For articles that emphasize the disproportionate group of expectant mothers among the small group of remaining women, see, for example, Hoeffel, Arocha, "Jury Probes Beating Claims," Arocha, "Cuban Refugees Picket," Babcock, Arnett, de Lama.

${ }^{23}$ As many scholars have documented, the welfare state, and particularly AFDC, became a divisive battleground where conceptions of citizenship and belonging were negotiated in the 1970s. As Mariel Cubans entered the United States, attacks against AFDC had progressively chipped away at the social and economic citizenship of particularly poor female-headed households of color. Stigmatized as the undeserving "takers" of taxpayer dollars, these "welfare queens" became, according to Julilly Kohler-Hausmann, the "grounds to deny calls for broader social rights and undermine newly established welfare rights and income support" (205).
} 
"eighty percent of these aliens will live off Uncle Sugar" or "us taxpayers" for most of the remainder of their lives." He or she also protested the praise of a large refugee family recently featured in the paper, arguing, "It is bad enough that none of the [woman's] children never have had a job and she is their sole support but one of her children has a mental condition and will never [sic] be able to support himself." Complaining of having "been shafted by Carter's holier-than-thou policies," the writer ultimately objected to the support of "these so-called aliens" in a time when citizens like himself or herself had a hard time benefitting from similar services. In addition to calling into question the poverty and deservingness of the Cubans, the author alloted significant blame to the Carter Administration, which had already "saddled" taxpayers with the cost of "our own citizens riding the welfare rolls" ("Public Forum"). This regional indictment of the Cuban problem reflected the broader economic resentment Americans aired in editorials and letters to the editor during these months and specifically singled out refugee women, mothers, and their yet to be resettled families. Although feature stories on Indiantown Gap's arriving families may have initially placated local residents concerned about the larger influx of young, unaccompanied Cuban men, it did not take long until taxpayers also directed resentment towards refugee families.

As Summer transitioned into Fall, many continued to blame the group's economic burden and lack of preparedness for American life on the failures of the federal resettlement effort. In an October issue of the Miami Herald, members of the Army lamented the negative transformations that occurred after the State Department assumed responsibility for the refugees. The Army further criticized the Task Force for suspending productive camp endeavors that prepared refugees for American life, including job training programs, as part of their broader critique of the camp's heightened militarization and penal functions. While the Task Force defended the lack of training on the grounds that it might "be giving the refugees something that most American citizens might not be able to get," it simultaneously stood behind its plan to "get the refugee on the outside as soon as possible and let social services pick them up in the normal system" (Arnold). As the year came to a close, The New York Times discussed additional economic costs of the government's monumental \$50 million resettlement effort (Hoeffel). Situating the Cubans squarely within a more ominous deluge of economically-marginalized late Cold War migrants, journalist Paul Heath Hoeffel argued that the "unprepared and unskilled immigrants ... may be the beginning rather than the end of a problem of national and international proportions." He maintained, "With new waves of unskilled and unprepared immigrants arriving regularly on these shores, [compounds like Fort Chaffee] threaten to become a permanent fixture of America's crisis-ridden immigration policy." The Times's lengthy examination of Fort Chaffee's "unwanted Cubans" emphasized much of the population's inevitable institutionalization, as well as the camp's "enforced vagrancy" and nearly 100\% level of unemployment. Moreover, the lack of an effective birth control policy in the camp had, according to Hoeffel, resulted in at least fifty pregnancies (out of a remaining 120 women) conceived in federal custody in the previous months. ${ }^{24}$ These public critiques of federal policy and disagreements among officials reinforced both the refugees' lack of preparedness for American life and the ways in which the government was implicated in that problem ("Riots and Stones at Fort Chaffee"). No matter where the blame was placed, perceived federal lack of support for Cuban selfsufficiency worked alongside these other 'marks' against the un-resettled group to construct a recognizable Cuban underclass at Fort Chaffee (Pogue).

The federal government decided in October to allow Cuban entrants to access increased financial assistance, as if they had, in fact, been classified as refugees. ${ }^{25}$ But the economic backlash to the new arrivals continued into the post-consolidation period. As the remaining Cubans settled into Fort Chaffee, gendered and racialized resentment became further entrenched. Journalists increasingly sought to understand why the sponsorship process had significantly slowed down. In October, The Washington Post determined that Fort Chaffee had become the "most visible symbol of this continuing national problem" (Babcock). In consultation with VOLAGS and federal officials, the newspaper ultimately attributed the widespread resistance to Cuban sponsorship on the remaining refugees' Blackness, perceived criminality and mental illness, and lack of education, job experience, and English language fluency.

\footnotetext{
${ }^{24}$ Leo Chavez has argued that the Latina immigrant is frequently represented as a threat to the nation on account of her out of control' fertility. In the context of a struggling economy, heightened immigration anxiety, and the changing demographic characteristics of new Cuban arrivals, the meanings associated with growing Cuban refugee families in the United States were not surprisingly in flux. See also Zaretsky for the ways in which the changing American family (and its anxieties) became central to fears of national decline in the 1970s.

${ }^{25}$ The Fascell-Stone Amendment of the Refugee Education Assistance Act, the piece of legislation that enabled the new Cubans to take fuller advantage of federal assistance, finally enabled states and local communities to be $100 \%$ reimbursed for the services, education, and health care benefits they had spent to assist the Cubans, a step that state and local officials had heavily lobbied for in the preceding months.
} 
From the fall of 1980 into the early months of 1981, the problems that pregnant women posed to the resettlement process appeared most prominently in discussions about Fort Chaffee's disproportionate Black population. The Miami Herald emphasized that most remaining refugees had "at least one strike" against them. In addition to pregnancy, other pathologizing "strikes" against the group included having a disability, a criminal record, a mental health issue, or merely being Black (Arocha, "Jury Probes Beating Claims"). According to VOLAGS, in addition to the increased costs and care they required, Black, pregnant women evaded resettlement in a sponsorship culture that continued to prefer 'whites only' (D. Williams). Finally, as part of a growing group of Cubans who had once again become the responsibility of the federal government, Black expectant mothers simultaneously served as the face of failed or "broken" sponsorships (D. Williams, Hoeffel). Detained in a high-security section of the Fort alongside the "troublemakers," one of these returning women was reported to be suffering from syphilis (D. Williams). While this factor played a role in the woman's return to Fort Chaffee, it also sexualized expectant Cuban mothers and linked them to another recognizable fixture of camp life: the refugee prostitute.

As Fort Chaffee neared its first anniversary of hosting Cubans, overt discussions about the economic costs of the camp's unconventional families heightened the racial understanding of resettlement failure. In the spring of 1981, sporadic episodes of violence and refugee protests prompted journalists to circle back to the "hard to place" Cubans who remained behind, this time with renewed emphasis on the mounting costs of maintaining the program both inside and outside of the Fort. Pregnant women and refugees who had recently given birth came to represent one of the largest costs, both literally and metaphorically, of the nation's decision to admit Mariel Cubans. As historian Julilly Kohler-Hausmann has demonstrated, the antiwelfare campaigns of the 1970s "activated racialized and gendered stereotypes to explain complex social transformations as the fault of distinct, degraded social groups." They "helped organize and amplify distinct, derogatory public scripts" about federally-supported families and "further concretized the association between cultural pathology and African American and Latina mothers" (183). In the context of growing backlash against the federal financial support of Black and Brown unwed mothers, Mariel women became not only important symbols of the deviance of Castro's Cuba, but also the criminalized scapegoats of resentment against federal welfare policy. ${ }^{26}$ A popular April 1981 AP story emphasized the "single young women" who "bear children conceived in the American resettlement camp" and focused readers' attention on the intertwined social and economic stakes of integrating the remaining Mariel women into society. By noting that many of these unwed mothers also had minimal education and "low-grade" skills, "with the Cubans falling through the revolving doors of joblessness," the story helped to mobilize an already resentful base of taxpayers against federal support of these unaccompanied and unmarried women (Arnett). The Arkansas Gazette similarly suggested that, among the camp's other "misfits," the "young women in the process of having children born out of wedlock" would almost surely become welfare recipients at this point in the resettlement effort. Encouraging the transfer of Fort Chaffee's expectant mothers to private maternity homes where they would be "better off," the Gazette reflected continued local dissatisfaction with having to bear the burden of Washington's distasteful resettlement agenda ("Riots and Stones at Fort Chaffee").

Adding to the anxieties of local Arkansans who feared a permanent detention center in their midst, resettlement officials consistently emphasized that pregnant women would need transitional care in halfway houses to be resettled (Arnold, Arocha, "Cuban Refugees Picket," Arnett). Unaccompanied women and their unconventional camp families were even harder to move out of Fort Chaffee than women who wanted to be sponsored independently. Officials insisted that a "very specific program," in which they contracted out services to private groups, was required to successfully resettle Mariel women, their young infants, and in many cases, their new male partners. In addition to a new or expectant mother's history of drug abuse or a prison record, for example, her unconventional family structure simultaneously placed her in the 'hard to place' sponsorship category. Indeed, officials pointed specifically to unwed mothers when they maintained that the remaining Cubans, unfortunately for sponsorship sake, did not "come in nice square little packages" (Parsons). In 1980, unconventional Mariel families not only challenged a long history of U.S. immigration

\footnotetext{
${ }^{26}$ The literature on AFDC recipients' relationship to the declining American welfare state is vast, and scholars point to the decades prior to 1980 as defining and pivotal moments in the history of that relationship. As AFDC rolls grew significantly by the early 1970s, "AFDC faced intensifying attacks and increasingly became a centerpiece in arguments that positioned poor mothers as the source of social disorder" (Kohler-Hausmann 134). As many scholars have demonstrated, this backlash was fundamentally a racial one, as many Americans came to (wrongly) understand AFDC as a program that primarily served African Americans and other women of color. For more on how public policy towards Black mothers served as a tool for maintaining racial hierarchies and white supremacy, see Solinger p. 235. For more on the postwar pathological construction of Black illegitimacy, see also Kunzel.
} 
policy favoring family reunification and disfavoring female-headed families, but they also entered the nation at a moment when the "crisis of the American family" had fully animated domestic politics. According to historian Regina Kunzel, "race-specific etiologies of illegitimacy [have] illuminated the ways in which gender and sexuality were enlisted in constructing racial hierarchies" (323). As the 1970s turned into a new decade, recent social and economic transformations in the American family and the racialized anxieties and political debates they produced influenced the stigmatization of Mariel women. ${ }^{27}$

By this point, young Cuban mothers at Fort Chaffee had become deeply embedded in a larger public discussion about long-term care and the institutionalization of mentally ill and other "unwanted" refugees. While comparing the expanded federal efforts to support both new mothers and the mentally ill population, reporters and officials often reinforced the notion that these groups were fundamentally one and the same (de Lama). In an especially damaging depiction of the Cubans that failed to critically interrogate the range of mental health issues that refugees faced in prolonged custody, the Associated Press counted young mothers among the refugees who "range from the depressed sitting quietly in corners, to the suicidal who swallow light bulbs and bed springs, and cut their wrists to get a nurse's attention" (Arnett). Another AP story that ran in the local Fort Smith paper, the Southwest Times Record, referred to two young refugee mothers as Castro's "human bullets," who became pregnant in the custody of the U.S. government despite their apparent inability to care for their children (Associated Press, "Chaffee's Mentally Ill"). Although not the only resettlement issue to galvanize state and local antipathy towards the federal government, the potential longterm institutional support of Fort Chaffee's unconventional families certainly fueled the national debate.

Whether Mariel women's perceived prolonged cost to the federal government and the taxpayer was rooted in their Blackness, status as unmarried mothers, poverty, and mental health, or a combination of these factors, the public discussion about these women at Fort Chaffee ultimately focused on their potential to become public charges. While the pathologization of Mariel men continued to be based on their perception as criminals suited for mass incarceration, anxieties about Mariel women in federal custody increasingly tapped into both contemporary and historical meanings of unwed motherhood and the perceived moral and economic threats these women posed to the nation. Ultimately, as longstanding gendered perceptions of foreignness merged with more recent critiques of the American welfare state, this changing understanding of Cuban migrant women and their families represented a pivotal shift in the nation's reception of Cuban exiles.

\section{Conclusion}

In a shifting political climate, in which the distinction between political refugees and economic or "illegal" migrants continued to blur, refugee women served as a topic of discussion among federal and other officials, ordinary Americans, and Cubans themselves. ${ }^{28}$ Mariel women became inextricably linked to arguments levied in the debates surrounding the Mariel crisis. Centering gendered forms of perceived disorder in resettlement camps illuminates how various groups and institutions not only debated the desirability of Mariel Cubans at a crucial moment in U.S. immigration history, but also how they negotiated their own role and stakes in the resettlement process. Despite these vastly different stakes, nearly all of these interests became implicated in the construction of Mariel difference and the heightened scrutiny of the refugee community. Tensions that developed among these various groups, including among refugees themselves, contributed to the camps' "disorderly" structure and atmosphere, the public's negative perceptions of the refugees, and in turn, the ongoing militarization of every facility from Pennsylvania to Arkansas. Not merely a response to perceived refugee "disorder," this militarization ultimately contributed to these detrimental perceptions.

Building on scholarship that has demonstrated how issues of bureaucracy and federalism contributed to the stigmatization of Mariel Cubans, this article suggests that we cannot fully understand the conflicts that plagued these relationships without understanding how Mariel women and gendered concerns were deeply implicated in these dynamics. Initial assessments of the resettlement effort highlight how ubiquitous the criminal characterization of unaccompanied Cuban migrant women had become even prior to Cuban

\footnotetext{
${ }^{27}$ Historians have thoroughly examined the transformation of the American family in the 1970s, as well as the political, economic, and social anxieties that arose as a result of these changes. In particular, the rising rate of divorce, the increase in female-headed families, and the entrance of more (married) women into the workforce progressively undermined the prevailing system of breadwinner liberalism and the concept of the family wage. See, in particular, Self 309-310, Zaretsky 19. Indeed, this "crisis of the American family" influenced the anti-welfare politics of both the Democratic and Republican parties in the 1970s, further reinforcing distinctions between the deserving white, male breadwinner and undeserving poor single mothers (Chappell 143).

${ }^{28}$ For more on the politics of these national policy changes, see, for example, Tichenor; Bon Tempo.
} 
women's arrival at regional resettlement camps. While local reporters demonstrated an eagerness to obtain the 'truth' of rumors that placed Cuban prostitutes in the boatlift's arrivals, many new arrivals were personally eager to dispel these rumors and necessarily complicate one-dimensional, damaging perceptions of the group. While they awaited sponsorship in the camps, Mariel women referenced the issue of prostitution specifically to clarify some of the discursive transnational origins of this trope. Aware of the label's stigmatizing influence in both countries, Cuban women and their families testified to the hardships they faced leaving Cuba and the necessity of claiming to be prostitutes, for example, in order to gain permission to emigrate. ${ }^{29}$ While these individual testimonies contested the validity of nationally circulated stereotypes about Mariel women specifically, they more broadly served to destigmatize the broader racialized understandings of Mariel Cubans that were developing simultaneously.

Despite these dissenting voices, gendered understandings of camp "disorder" nonetheless effectively contributed to Mariel stigmatization. While the "insights" offered by various camp actors inextricably linked Mariel women to the stigmatization of the larger group, they also reveal important elements of the gendered processes through which this racialization was conceived. By connecting Mariel women's sexuality to the deviance of the Castro regime, the issue of prostitution allowed various groups, starting with civilian and military law enforcement officials, to question the desirability of Mariel Cubans. And by highlighting the broader economic precarity of unaccompanied Mariel mothers, these various interests tapped into both historical and contemporary understandings of women's potential to become public charges. In the context of the recent Carter Administration's "open arms" embrace of its newest arrivals, public references to Mariel women's sexual deviance and economic marginality ultimately served to ridicule the government's acceptance of Cuban refugees and the longstanding political and ideological arguments that had justified their belonging. ${ }^{30}$ Rather than understanding Mariel women to be freedom-seeking victims and potential future redeemers of Castro's Cuba, unaccompanied women of the Mariel exodus were understood to be degenerate products of his failed regime. In the end, rather than emphasizing the new Cubans' affinity to Americans and their potential to become good citizens, these gendered discourses allowed Americans to frame the conversation about their status around the question of their difference.

\section{Competing Interests}

The author has no competing interests to declare.

\section{References}

"A Report of the Cuban-Haitian Task Force." Box 24, Folder 126 "Documents: A Report of the CHTF, Nov. 1980." CHC0218 Cuban Refugee Center Records. Cuban Heritage Collection, University of Miami, Coral Gables, FL.

Adams, Roger C. Letter to Christian R. Holmes. 18 August 1980. Box 48, Folder "Chron - Internal, 8/1121/80." RG 220 Records of the Cuban-Haitian Task Force. Jimmy Carter Presidential Library, Atlanta, GA.

Aguirre, B. E. "Cuban Mass Migration and the Social Construction of Deviants." Bulletin of Latin American Research, vol. 13, no. 2, 1994, pp. 155-183. DOI: https://doi.org/10.2307/3338273

Arnett, Peter. "Floundering in Wake of Freedom Flotilla." New York Daily News, 20 April 1981.

Arnold, Michael. "Cubans Left at Chaffee Developing Mood of Resignation." Arkansas Gazette, 21 November 1980.

Arocha, Zita. "Cuban Refugees Picket Over Resettlement Delay." Miami Herald, 15 March 1981.

---. "Jury Probes Beating Claims at Ft. Chaffee." Miami Herald, 4 February 1981.

Associated Press. "2 Cuban Women Jailed from 'Gap.'” Lancaster New Era, 12 June 1980.

---. "Chaffee’s Mentally Ill Called ‘Human Bullets." Southwest Times Record, 22 April 1981.

---. "Two Cuban Women Sent to Cambria." Somerset Daily American, 12 June 1980.

Babcock, Charles. "Resettling of Cuban Refugees is Proceeding at a Slow Pace: Criminal Records, Homosexuality, Mental Illness are Factors." Washington Post, 10 February 1981.

\footnotetext{
${ }^{29}$ See, for example, Keegan, for the Chicago Tribune's first impressions of For McCoy. New refugees were not the only ones who sought to clarify why many women had claimed to be prostitutes in order to leave Cuba. As the issue of prostitution became a more frequently referenced fixture of camp life, members of the Cuban American community, religious authorities, VOLAGS, and other officials helping to resettle Mariel Cubans at these sites also joined the effort to educate Americans about the roots of this circulating stereotype. For more examples throughout the summer of 1980, see, for example, Durrett; Rivero; and Nickeson.

30 "Open arms" is a reference to President Carter's speech made to the League of Women Voters in Philadelphia on May 3, in which he pledged the U.S.'s continued embrace of refugees fleeing Cuba.
} 
Bach, Robert L, Jennifer B. Bach, and Timothy Triplett. "The Flotilla 'Entrants': Latest and Most Controversial." Cuban Studies, vol. 11 no. 2, 1981, pp. 29-48.

Bon Tempo, Carl J. Americans at the Gate: The United States and Refugees During the Cold War. Princeton University Press, 2008. DOI: https://doi.org/10.1515/9781400829033

Briquets, Sergio Diaz. "Demographic and Related Determinants of Recent Cuban Emigration." International Migration Review, vol. 17 no. 1, 1983, pp. 95-119. DOI: https://doi. org/10.1177/019791838301700104

Buelow, Michael. "Interpreter Ends Up Taking Refugees Home." La Crosse Tribune [La Crosse, WI], 21 June 1980.

Capo, Jr., Julio. "Queering Mariel: Mediating Cold War Foreign Policy and U.S. Citizenship among Cuba's Homosexual Exile Community, 1978-1994." Journal of American Ethnic History, vol. 29 no. 4, 2010, pp. 78-106. DOI: https://doi.org/10.5406/jamerethnhist.29.4.0078

Casavantes Bradford, Anita. The Revolution is for the Children: The Politics of Childhood in Havana and Miami, 1959-1962. University of North Carolina Press, 2014. DOI: https://doi.org/10.5149/ northcarolina/9781469611525.001.0001

"Castro's Big Joke." Southwest Times Record, 23 April 1981.

Chappell, Marisa. The War on Welfare: Family, Poverty, and Politics in Modern America. University of Pennsylvania Press, 2010. DOI: https://doi.org/10.9783/9780812201567

Chavez, Leo. The Latino Threat: Constructing Immigrants, Citizens, and the Nation. Stanford University Press, 2008.

Cox-Herion, Marilyn. "Anxiety, Frustration Linger as Days Wear On." Shreveport Times, 8 June 1980.

"Cuban Entrant Data." Box 16, Folder "Reading File." RG 220 Records of the Cuban-Haitian Task Force. Jimmy Carter Presidential Library, Atlanta, GA.

Current, Cheris Brewer. "Normalizing Cuban Refugees: Representations of Whiteness and Anti-communism in the USA During the Cold War." Ethnicities, vol. 8 no. 1, 2008, pp. 42-66. DOI: https://doi. org/10.1177/1468796807087019

de Lama, George. "Final Chapter on Cubans is Tough to Write." Chicago Tribune, 26 April 1981.

de los Angeles Torres, María. In the land of Mirrors: Cuban Exile Politics in the United States. University of Michigan Press, 1999.

Department of the Army. Task Force Resettlement Operation, After Action Report, Fort Chaffee, Arkansas, 7 May 1980-19 February 1982. Fort Sill, OK, Department of the Army, 1982.

Dow, Mark. American Gulag: Inside U.S. Immigration Prisons. University of California Press, 2004. DOI: https://doi.org/10.1525/9780520939271

Durrett, Craig. "Chaffee: Qualms Follow Chaos." Shreveport Times, 8 June 1980.

Escobedo, Elizabeth R. "The Pachuca Panic: Sexual and Cultural Battlegrounds in World War II Los Angeles." Western Historical Quarterly, vol. 38 no. 2, 2007, pp. 133-156. DOI: https://doi.org/10.1093/ whq/38.2.133

Espiritu, Yen Le. Body Counts: The Vietnam War and Militarized Refugees. University of California Press, 2014. DOI: https://doi.org/10.1525/9780520959002

Fiedler, Tom and Guy Gugliotta. "How Resettlement Has Become a Mess." Miami Herald, 1 June 1980.

"FEMA/Miami Coordination - Mr. Casey and Col. McKee (16 May 80)." 16 May 1980. Box 1, Folder 7 "Gastón A. Fernández: Federal Control Center Documents, 1980" CHC5175 Fort Chaffee Collection. Cuban Heritage Collection, University of Miami, Coral Gables, FL.

García, María Cristina. "Hardliners v." Dialogueros": Cuban Exile Political Groups and United States-Cuba Policy." Journal of American Ethnic History, vol. 17, no. 4, 1998, pp. 3-28.

---. Havana U.S.A.: Cuban Exiles and Cuban Americans in South Florida, 1959-1989. University of California Press, 1996.

Gardner, Martha. The Qualities of a Citizen: Women, Immigration, and Citizenship, 1870-1965. Princeton University Press, 2005. DOI: https://doi.org/10.1515/9781400826575

Gordon, Bill. "A Taste of Midwest for Cubans." Des Moines Tribune, 26 June 1980.

Hamm, Mark S. The Abandoned Ones: The Imprisonment and Uprising of the Mariel Boat People. Northeastern University Press, 1995.

Hoeffel, Paul Heath. "Fort Chaffee's Unwanted Cubans." New York Times, 21 December 1980.

Hufker, Brian and Gray Cavender. "From Freedom Flotilla to America's Burden: The Social Construction of the Mariel Immigrants." Sociological Quarterly, vol. 31 no. 2, 1990, pp. 321-335. DOI: https://doi. org/10.1111/j.1533-8525.1990.tb00331.x 
Hynson, Rachel. Laboring for the State: Women, Family, and Work in Revolutionary Cuba, 1959-1971. Cambridge University Press, 2019. DOI: https://doi.org/10.1017/9781108105330

Jacklin, Jillian Marie. "The Cuban Refugee Criminal: Media Reporting and the Production of a Popular Image." International Journal of Cuban Studies, vol. 11 no. 1, 2019, pp. 61-83. DOI: https://doi.org/10.13169/ intejcubastud.11.1.0061

Jaeger, Richard W. “U.S. Marshal Rides Herd at Refugee Center." Wisconsin State Journal, 30 June 1980.

Johnson, Terry E. and Jan Schaffer. "Inside Indiantown Gap: How Tempers Grew So Hot." Philadelphia Inquirer, 10 August 1980.

Keegan, Ann. "Stripped by Castro, but Free to Begin New Life." Chicago Tribune, 30 May 1980.

Knarr, Jack. "In 'Enemy Territory' in Arkansas." Miami News, 3 June 1980.

Kohler-Hausmann, Julilly. Getting Tough: Welfare and Imprisonment in 1970s America. Princeton University Press, 2017. DOI: https://doi.org/10.23943/princeton/9780691174525.001.0001

Kunzel, Regina. "White Neurosis, Black Pathology: Constructing Out-of-Wedlock Pregnancy in the Wartime and Postwar United States." Not June Cleaver: Women and Gender in Postwar America, 1945-1960, edited by Joanne Meyerowitz, Temple University Press, 1994, pp. 304-331.

La Libertad. 30 June 1980. Box 39, Folder "News Clippings, 6/27/80-7/19/80." RG 220 Records of the Cuban-Haitian Task Force. Jimmy Carter Presidential Library, Atlanta, GA.

Langenkamp, Don. "Tough Duty at Fort McCoy." Green Bay Press-Gazette, 15 June 1980.

Lawson, Barbara. Letter to Christian R. Holmes. 26 September 1980. Box 50, Folder "Cleared Letters, October 6-8, 1980." RG 220 Records of the Cuban-Haitian Task Force. Jimmy Carter Presidential Library, Atlanta, GA.

Lenton, Gary. "Atmosphere Tense at Gap: Refugee Mood Changing." Lebanon Daily News [Lebanon, PA], 5 June 1980.

Lipman, Jana K. "A Refugee Camp in America: Fort Chaffee and Vietnamese and Cuban Refugees, 19751982." Journal of American Ethnic History, vol. 33 no. 2, 2014, pp. 57-87. DOI: https://doi.org/10.5406/ jamerethnhist.33.2.0057

Luibheid, Eithne. Entry Denied: Controlling Sexuality at the Border. University of Minnesota Press, 2002.

Lynn, Rene. "Military Policeman Happy to Flee Refugees." Clarion Ledger [Jackson, MS], 13 July 1980.

Malkki, Liisa H. "Refugees and Exile: From 'Refugee Studies' to the National Order of Things." Annual Review of Anthropology, vol. 24, 1995, pp. 495-523. DOI: https://doi.org/10.1146/annurev.an.24.100195.002431

McMahon, Patrick. "Cuban Refugees are Anxious, Frustrated." St. Petersburg Times, 1 June 1980.

Moloney, Deirdre M. National Insecurities: Immigrants and U.S. Deportation Policy Since 1882. University of North Carolina Press, 2012.

Ngai, Mae M. Impossible Subjects: Illegal Aliens and the Making of Modern America. Princeton University Press, 2004

Nickeson, Sandra. "Resettlement Begins for Cubans at McCoy." Oshkosh Northwestern, 28 July 1980.

"Operational Summary (23 May) FEMA/Other Federal Agencies Support Requirements." 23 May 1980. Box 1, Folder 7 "Gastón A. Fernández: Federal Control Center Documents, 1980" CHC5175 Fort Chaffee Collection. Cuban Heritage Collection, University of Miami, Coral Gables, FL.

Parsons, Paul [Associated Press]. "Fort Chaffee: After One Year." Fort Myers News-Press, 10 May 1981.

Pedraza-Bailey, Silvia. Political and Economic Migrants in America: Cubans and Mexicans. University of Texas Press, 1985.

Peña, Susana. Oye Loca: From the Mariel Boatlift to Gay Cuban Miami. University of Minnesota Press, 2013. DOI: https://doi.org/10.5749/minnesota/9780816665532.001.0001

Pereira, Sergio. Letter to Chris Holmes. 20 August 1980. Box 48, Folder “Chron - Internal, 8/11-21/80." RG 220 Records of the Cuban-Haitian Task Force. Jimmy Carter Presidential Library, Atlanta, GA.

---. Letter to Victor H. Palmieri. 27 June 1980. Box 50, Folder "Cleared Letters, October 6-8, 1980." RG 220 Records of the Cuban-Haitian Task Force. Jimmy Carter Presidential Library, Atlanta, GA.

Perez, Miguel. "Cubans Jailed Here Say Liberty's Lamp is Flickering." New York Daily News, 5 June 1980.

Pew, Frank W. The Role of FORSCOM in the Reception and Care of Refugees from Cuba in the Continental United States. Ft. McPherson, GA: FORSCOM, 1984.

Pogue, Jan. "The Gay Cubans: Last Stop Phila for the Refugees Nobody Wanted." Philadelphia Inquirer, 28 June 1981.

Portes, Alejandro and Alex Stepick. City on the Edge: The Transformation of Miami. University of California Press, 1993. 
"Problems Encountered by GSA Region 3 Support of the Fort Indiantown Gap Cuban-Haitian Task Force." Box 49, Folder "Chron - Internal, 2/81." RG 220 Records of the Cuban-Haitian Task Force. Jimmy Carter Presidential Library, Atlanta, GA.

"Public Forum: Alien Woes." Lebanon Daily News [Lebanon, PA], 3 June 1980.

Ramirez, Catherine S. The Woman in the Zoot Suit: Gender, Nationalism, and the Cultural Politics of Memory. Duke University Press, 2009. DOI: https://doi.org/10.2307/j.ctv1131895

"Riots and Stones at Fort Chaffee." Arkansas Gazette, 26 April 1981.

Rivero, Alina. "Cuban Refugees: Hope, Then Confusion and Despair." St. Louis Post-Dispatch, 15 June 1980. Rose, Willard P. "Refugees Demonstrate, Demand to be Released." Miami Herald, 31 May 1980.

Ruiz, Vicki L. From out of the Shadows: Mexican Women in Twentieth-Century America. Oxford University Press, 1998.

Self, Robert O. All in the Family: The Realignment of American Democracy Since the 1960s. Hill and Wang, 2012.

Shelton, Terry. "Cubans Try to Govern Selves." La Crosse Tribune [La Crosse, WI], 6 June 1980.

Shull, Kristina. "Nobody Wants These People': Reagan's Immigration Crisis and the Containment of Foreign Bodies." Body and Nation: The Global Realm of U.S. Body Politics in the Twentieth Century, edited by Emily S. Rosenberg and Shanon Fitzpatrick, Duke University Press, 2014, pp. 241-64. DOI: https://doi. org/10.2307/j.ctv120qsd2.15

"Significant Activities 17 May." 18 May 1980. Box 1, Folder 7 "Gastón A. Fernández: Federal Control Center Documents, 1980" CHC5175 Fort Chaffee Collection. Cuban Heritage Collection, University of Miami, Coral Gables, FL.

Solinger, Rickie. Wake Up Little Susie: Single Pregnancy and Race Before Roe v. Wade, $2^{\text {nd }}$ ed., New York: Routledge, 2000.

Tichenor, Daniel J. Dividing Lines: The Politics of Immigration Control in America. Princeton University Press, 2002. DOI: https://doi.org/10.1515/9781400824984

United Press International. "2 Cuban Women Jailed from 'Gap.'” Huntingdon Daily News [Huntingdon, PA], 12 June 1980.

---. "Troops Find Weapons in Search at Refugee Camp." New York Times, 7 June 1980.

Viglucci, Andres. "For Cubans, Filling a Gap in Time." Pittsburgh Press, 6 July 1980.

Waldschmidt, Paul (United Press International). “'Wrong Side of Tracks' Develops in Refugee Camp.” Pittsburgh Press, 4 June 1980.

White, Bill. "Refugee Leaders to See All Resettled." La Crosse Tribune [La Crosse, WI], 7 July 1980.

Williams, Dan. "Sifted Out: Humans at Fort Have Become Human Chaff." Miami Herald, 19 October 1980.

Williams, John. "The ‘Oldest Profession' Enjoys Captive Clientele Inside Campo Libertad." Orlando Sentinel, 30 May 1980.

Wilks, Sara. "Writer Helps Women Bridge the Gap From 'Freedom City' to Freedom." Harrisburg Sunday Patriot News, 20 July 1980.

Zaretsky, Natasha. No Direction Home: The American Family and the Fear of National Decline, 1968-1980. University of North Carolina Press, 2007. DOI: https://doi.org/10.5149/9780807867808_zaretsky

How to cite this article: Hampton, M 2021 "A Tent City is Not a Place for a Family": Mariel Cuban Women and Gendered Disorder at Regional Resettlement Facilities. Anthurium, 17(2): 3, 1-17. DOl: https://doi.org/10.33596/ anth.447

Published: 14 December 2021

Copyright: (c) 2021 The Author(s). This is an open-access article distributed under the terms of the Creative Commons Attribution 4.0 International License (CC-BY 4.0), which permits unrestricted use, distribution, and reproduction in any medium, provided the original author and source are credited. See http://creativecommons.org/licenses/by/4.0/. 